ORNL/TM-2015/391

CRADA/NFE-14-04915

MDF-TC-2013-032

Technical assessment of roll-to-roll operation of lamination process, thermal

treatment, and alternative carbon fiber precursors for low-cost, high-efficiency

manufacturing of flow battery stacks and other energy devices

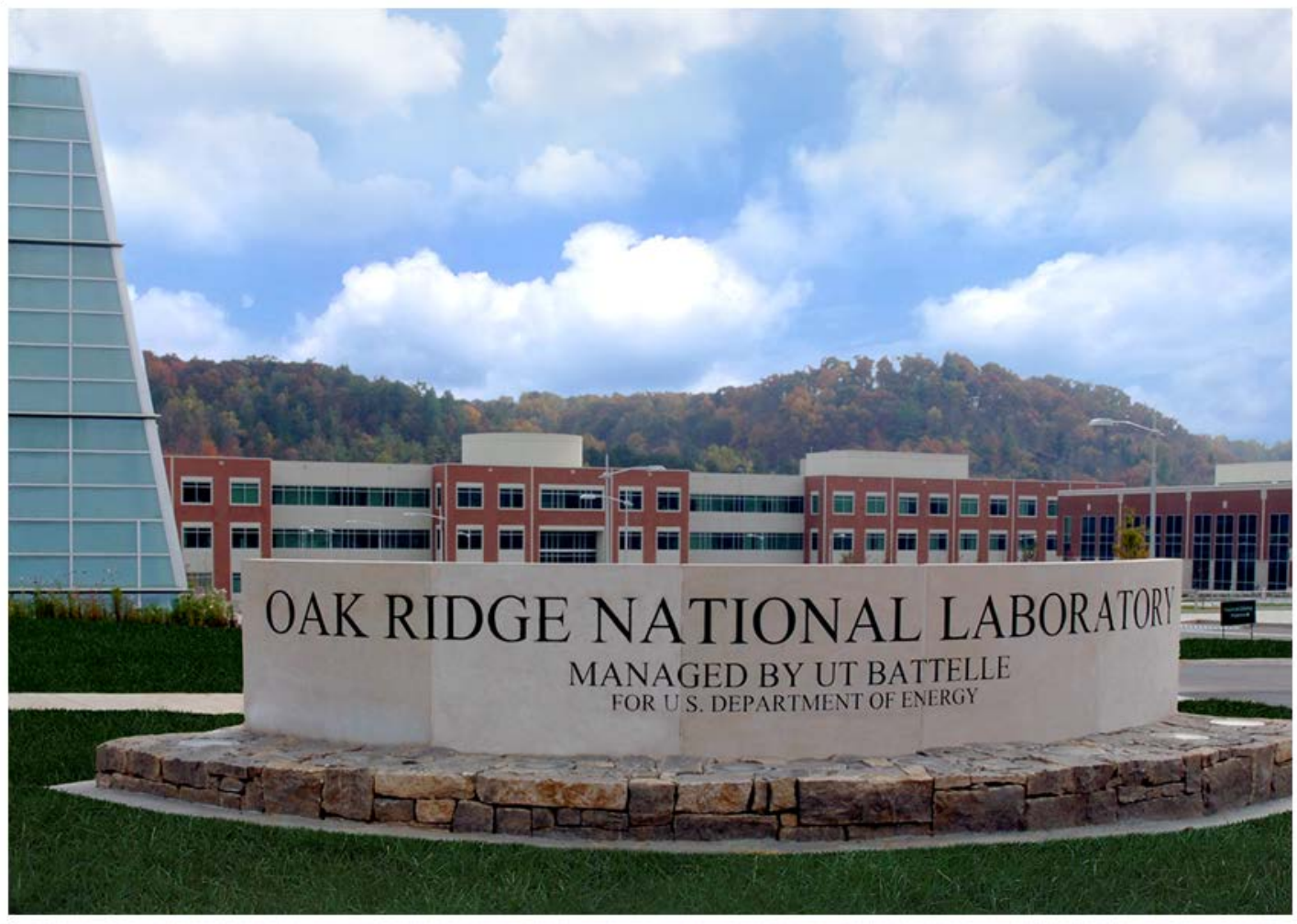

Claus Daniel, Thomas Madden, David Wood, Tom Muth, Curtis Warrington, Soydan Ozcan, Hunter Manson, Halil Tekinalp, Mark Smith, Yuan Lu, Jeremy Loretz September 23, 2015 


\section{DOCUMENT AVAILABILITY}

Reports produced after January 1, 1996, are generally available free via US Department of Energy (DOE) SciTech Connect.

Website http://www.osti.gov/scitech/

Reports produced before January 1, 1996, may be purchased by members of the public from the following source:

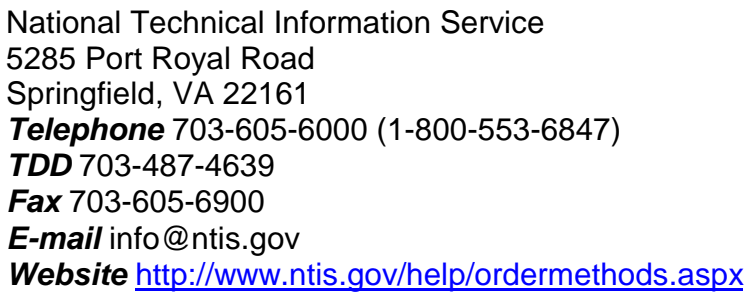

Reports are available to DOE employees, DOE contractors, Energy Technology Data Exchange representatives, and International Nuclear Information System representatives from the following source:

Office of Scientific and Technical Information

PO Box 62

Oak Ridge, TN 37831

Telephone 865-576-8401

Fax 865-576-5728

E-mail reports@osti.gov

Website http://www.osti.gov/contact.html

This report was prepared as an account of work sponsored by an agency of the United States Government. Neither the United States Government nor any agency thereof, nor any of their employees, makes any warranty, express or implied, or assumes any legal liability or responsibility for the accuracy, completeness, or usefulness of any information, apparatus, product, or process disclosed, or represents that its use would not infringe privately owned rights. Reference herein to any specific commercial product, process, or service by trade name, trademark, manufacturer, or otherwise, does not necessarily constitute or imply its endorsement, recommendation, or favoring by the United States Government or any agency thereof. The views and opinions of authors expressed herein do not necessarily state or reflect those of the United States Government or any agency thereof. 
ORNL/TM-2015/391

CRADA/NFE-14-04915

Energy and Transportation Science Division

Advanced Manufacturing Office

Technical assessment of roll-to-roll operation of lamination process, thermal treatment, and alternative carbon fiber precursors for low-cost, high-efficiency manufacturing of flow battery stacks and other energy devices

\author{
Authors \\ Claus Daniel \\ Thomas Madden \\ David Wood \\ Tom Muth \\ Curtis Warrington \\ Soydan Ozcan \\ Hunter Manson \\ Halil Tekinalp \\ Mark Smith \\ Yuan Lu \\ Jeremy Loretz
}

Date Published:

September 23, 2015

\author{
Prepared by \\ OAK RIDGE NATIONAL LABORATORY \\ Oak Ridge, Tennessee 37831-6283 \\ managed by \\ UT-BATTELLE, LLC \\ for the \\ US DEPARTMENT OF ENERGY \\ under contract DE-AC05-00OR22725
}

Approved for public release. 



\section{CONTENTS}

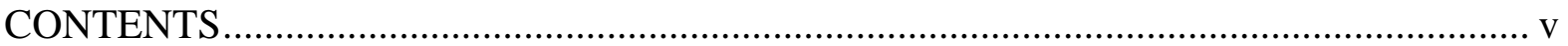

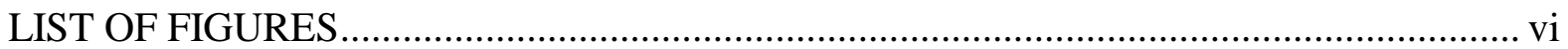

ACKNOWLEDGEMENTS ........................................................................................ vii

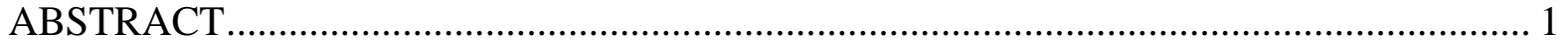

1. TECHNICAL ASSESSMENT OF ROLL-TO-ROLL OPERATION OF LAMINATION PROCESS, THERMAL TREATMENT, AND ALTERNATIVE CARBON FIBER PRECURSORS FOR LOW-COST, HIGH-EFFICIENCY MANUFACTURING OF FLOW BATTERY STACKS AND OTHER ENERGY DEVICES .......................................... 1

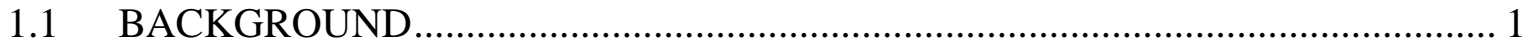

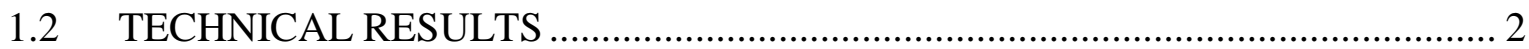

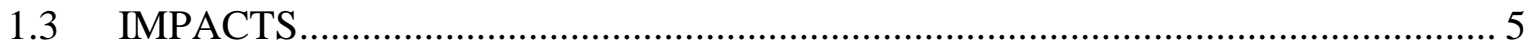

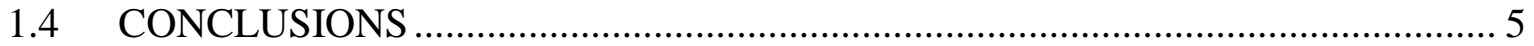

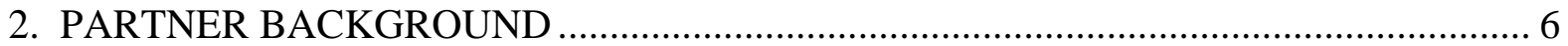




\section{LIST OF FIGURES}

Fig. 1. Fabrication of a) flow layers and b) bipolar layers in the DFMA stack. ..................... 2

Fig. 2. Bonding of test samples performed at ORNL. ..................................................... 3

Fig. 3. Experimental set up for pressure testing............................................................ 3

Fig. 4. kW-scale DFMA stack fabricated of only die-cut sheet goods. ................................ 4

Fig. 5. Charge / discharge polarization performance of the DFMA cell using proprietary

CCFB electrolytes. Conditions: $0.8 \mathrm{~L} / \mathrm{min}$ flow of posolyte \& negolyte, $\mathrm{T}=35{ }^{\circ} \mathrm{C}, 50 \%$ state-

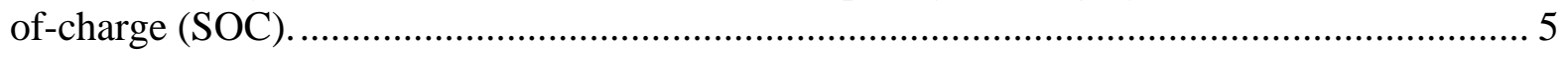




\section{ACKNOWLEDGEMENTS}

This CRADA NFE-14-04915 was conducted as a Technical Collaboration project within the Oak Ridge National Laboratory (ORNL) Manufacturing Demonstration Facility (MDF) sponsored by the US Department of Energy Advanced Manufacturing Office (CPS Agreement Number 24761).

Opportunities for MDF technical collaborations are listed in the announcement "Manufacturing Demonstration Facility Technology Collaborations for US Manufacturers in Advanced Manufacturing and Materials Technologies” posted at http://web.ornl.gov/sci/manufacturing/docs/FBO-ORNL-MDF2013-2.pdf. The goal of technical collaborations is to engage industry partners to participate in shortterm, collaborative projects within the Manufacturing Demonstration Facility (MDF) to assess applicability and of new energy efficient manufacturing technologies. Research sponsored by the U.S. Department of Energy, Office of Energy Efficiency and Renewable Energy, Advanced Manufacturing Office, under contract DE-AC05-00OR22725 with UT-Battelle, LLC. 



\begin{abstract}
Among the various stationary-storage technologies under development, redox flow batteries (RFBs) offer the greatest potential to deliver inexpensive, scalable, and efficient grid-scale electrical-energy storage. Unlike traditional sealed batteries, in a flow battery power and energy are decoupled. Cell area and cell count in the stack determine the device power, and the chemical storage volume determines the total energy. Grid-scale energy-storage applications require megawatt-scale devices, which require the assembly of hundreds of large-area, bipolar cells per power plant. The cell-stack is the single system component with the largest impact on capital cost (due to the large number of highly engineered components) and operating costs (determined by overall round-trip efficiency). Sun Catalytix (now Lockheed Martin Advanced Energy Storage, LLC) proposed to work with the Oak Ridge National Laboratory (ORNL) Manufacturing Demonstration Facility (MDF) to develop a transformational, design-for-manufacturing and assembly (DFMA) RFB stack architecture and corresponding manufacturing process and utilize low cost carbon fiber to achieve:

- Stack manufacturing/assembly times of $<15$ min per 100 large-area $\left(>1000 \mathrm{~cm}^{2}\right.$ ) cells

- Leveraging inexpensive carbon fiber technology currently in the development phase at ORNL for reduced material costs

- Low capital intensity for component and stack assembly methods

- No capital expense required for design changes

- Ability to rapidly prototype new designs using production equipment
\end{abstract}

Roll to roll manufacturing routes for DFMA were identified and options for flexible bipolar plate bonding have been developed and validated Samples plates were prepared and found sufficiently leak proof under pressure testing. A kW-scale, DFMA cell was then fabricated and also passed leak testing. Charge / discharge performance of the DFMA was tested. Cell resistance of the new design slightly exceeds the capabilities of the current traditional cell design which suggests that the DFMA design may not involve any performance trade-offs to achieve disruptively lower costs.

\title{
1. TECHNICAL ASSESSMENT OF ROLL-TO-ROLL OPERATION OF LAMINATION PROCESS, THERMAL TREATMENT, AND ALTERNATIVE CARBON FIBER PRECURSORS FOR LOW-COST, HIGH-EFFICIENCY MANUFACTURING OF FLOW BATTERY STACKS AND OTHER ENERGY DEVICES
}

This phase 1 technical collaboration project (MDF-TC-2013-032) was begun on December 1, 2013 and was completed on July 31, 2015. The collaboration is a large business. Roll to roll manufacturing routes for SunCatalytix's (now Lockheed Martin Advanced Energy Storage, LLC) design-formanufacturing and assembly (DFMA) have been identified and options for flexible bipolar plate bonding have been developed and validated.

\subsection{BACKGROUND}

Sun Catalytix was founded to discover and develop new earth abundant materials for energy conversion processes. The company is now developing an affordable, safe and scalable energy storage technology. Current efforts focus on the design, synthesis, and electrochemical testing of molecular redox shuttles for energy storage. The company's design principles prioritize earth-abundant materials with low cost that operate under benign conditions. This combination of attributes enables the design of energy 
storage systems that surpass the performance and cost achieved by all legacy chemistries. The company is also developing high-throughput manufacturing technology to ensure that its energy storage chemistry is capable of scaling to very high volumes demanded by the energy industry.

\subsection{TECHNICAL RESULTS}

Developing a DFMA stack architecture requires that the manufacturing processes that are involved are inherently rapid. This will tend to exclude processes with long cycle times that are commonly used in the fabrication of current flow battery stacks, including bipolar plate compression molding, bipolar plate machining, and hand-assembly of cells into stacks. A trial concept of a high throughput design is depicted below. The fabrication steps for individual layers in a DFMA stack are shown in Figure 1. In Figure 1a, die-cut thermoplastic films are thermally bonded into porous carbon felt to form a flow layer. Complete polymer impregnation occurs around the edge of the carbon felt media so that no fluid leakage occurs from the sides. In Figure 1b, thin carbon media are bonded on either side of a thermoplastic layer to form an impermeable layer capable of conducting electrons through-plane. Many rapid thermal processes are available to perform the functions in Figure $1 \mathrm{a}$ and $\mathrm{b}$, including hot rolling, laser welding, and ultrasonic welding. The layers in Figure 1 are subsequently bonded using further thermal processing with electrolyte membrane layers to form a full cell assembly. The flow features are aligned during the bonding so that a shunt-resistant plastic frame is formed with an integral, fluid manifold, while maintaining the throughplane electronic conduction of the active area. Additive buildup of these layers continues progressively to form the DFMA flow battery stack.

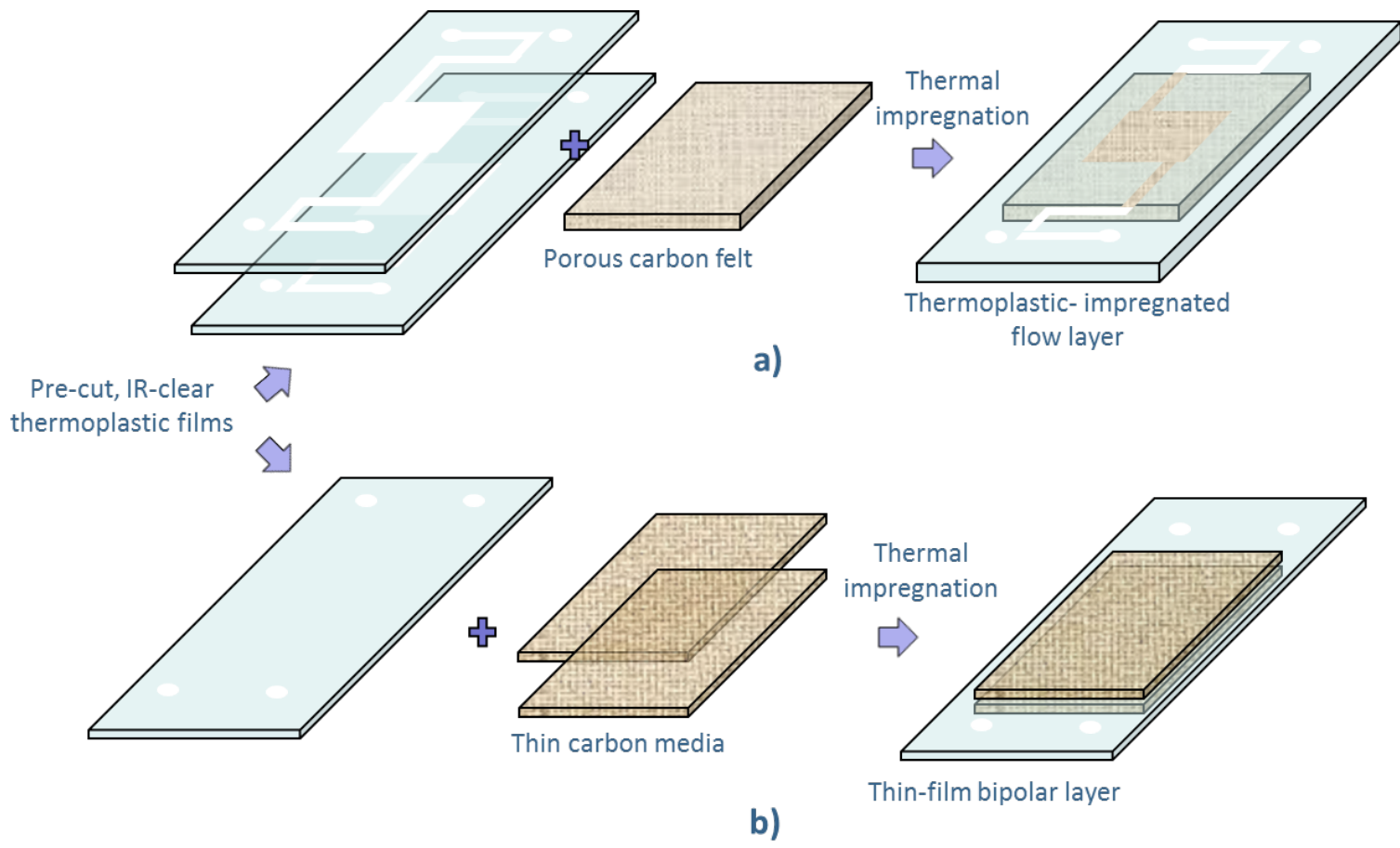

Fig. 1. Fabrication of a) flow layers and b) bipolar layers in the DFMA stack.

The porous carbon felt in Figure 1a is comprised of poly-acrylonitrile (PAN) fibers, which can be highly engineered in woven or non-woven matrices to impart the desired conductivity and flow characteristics. However, the thin carbon media in Figure $1 b$ has significantly reduced material requirements - it need only be electrically conductive, but structurally and fluidically robust to a lesser degree. Also, since there are two such layers per-cell, they are appropriate candidates for exploring the leveraging and 
implementation of non-PAN based carbon fiber development currently underway at ORNL.

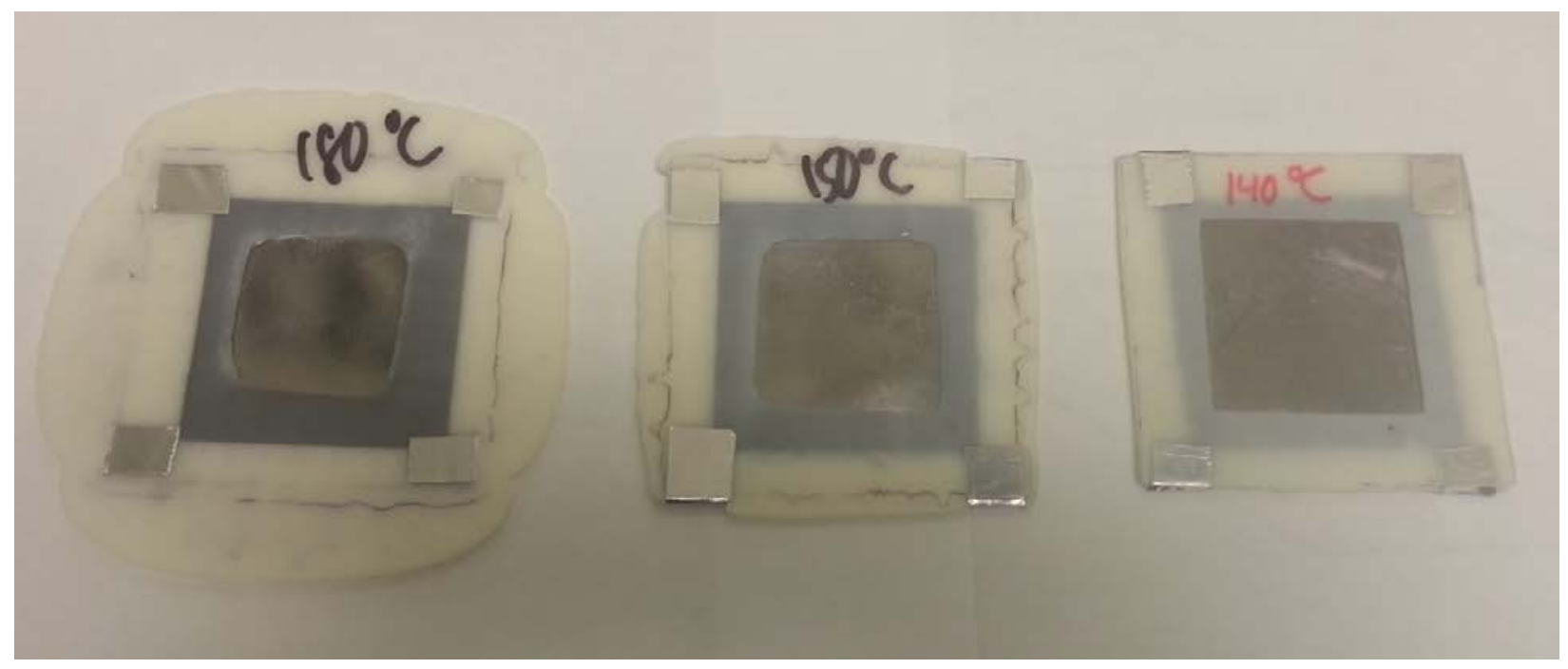

Fig. 2. Bonding of test samples performed at ORNL.
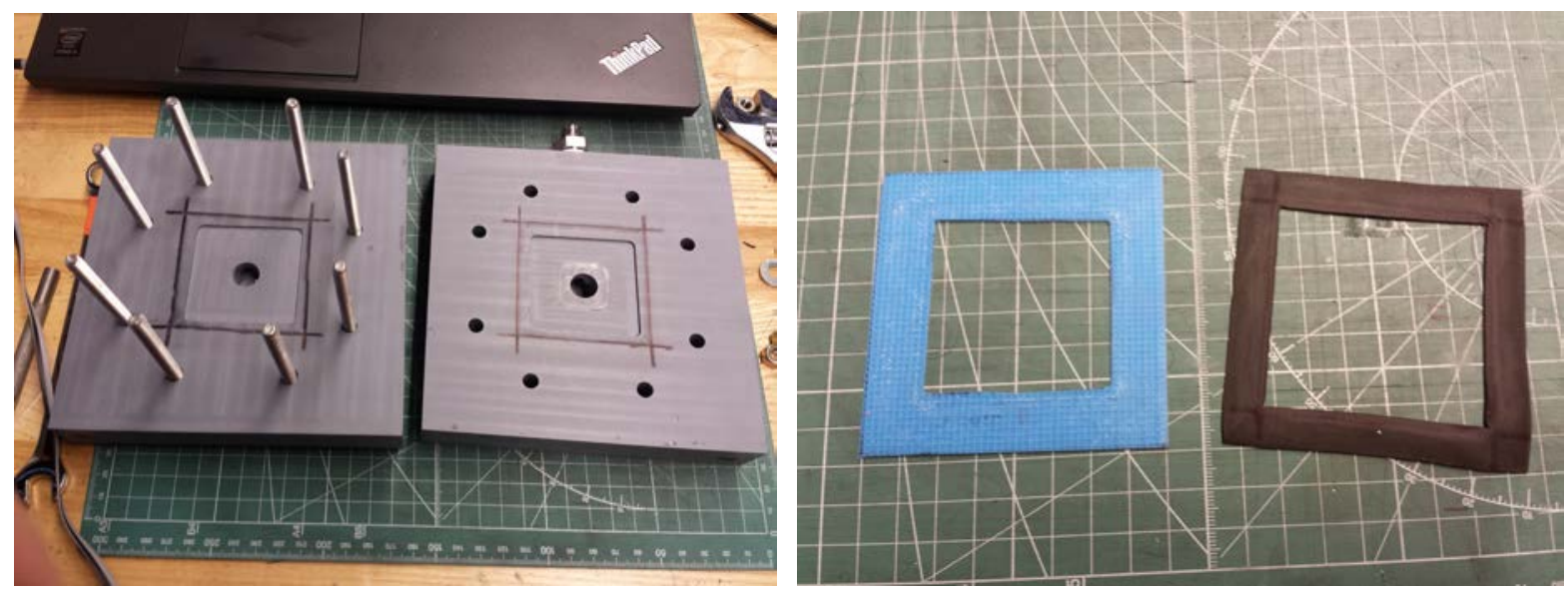

Fig. 3. Experimental set up for pressure testing.

The initial test of the samples prepared at ORNL was a failure test to determine the maximum pressure a sample plate could withstand before rupturing. Further tests used nitrogen gas to perform hold pressure tests. The team performed a pressure test with water to locate leaks in the parts, gaskets or fixture based on a visual check for moisture post-test. Four of the five test samples passed the leak test.

Based on the bonding / testing parameters generated above, a kW-scale, DFMA cell was fabricated. This cell, which interfaces to current $\mathrm{kW}$-scale hardware, features $400 \mathrm{~cm}^{2}$ active area cell, as depicted in figure 4. It incorporates carbon felt electrodes, PFSA-based membrane, and a special, rolled graphite sheets that comprise the central conductive section of the bipolar plates that are surrounded by ABS sheet frames. In keeping with the requirements of the project, this cell is fabricated with only sheet goods that are die-cut and adhesively bonded. After several iterations in bonding process development, this cell passed gas leakage testing and was tested with Lockheed Martin's proprietary Coordination Chemistry Flow Battery (CCFB) electrolytes. 


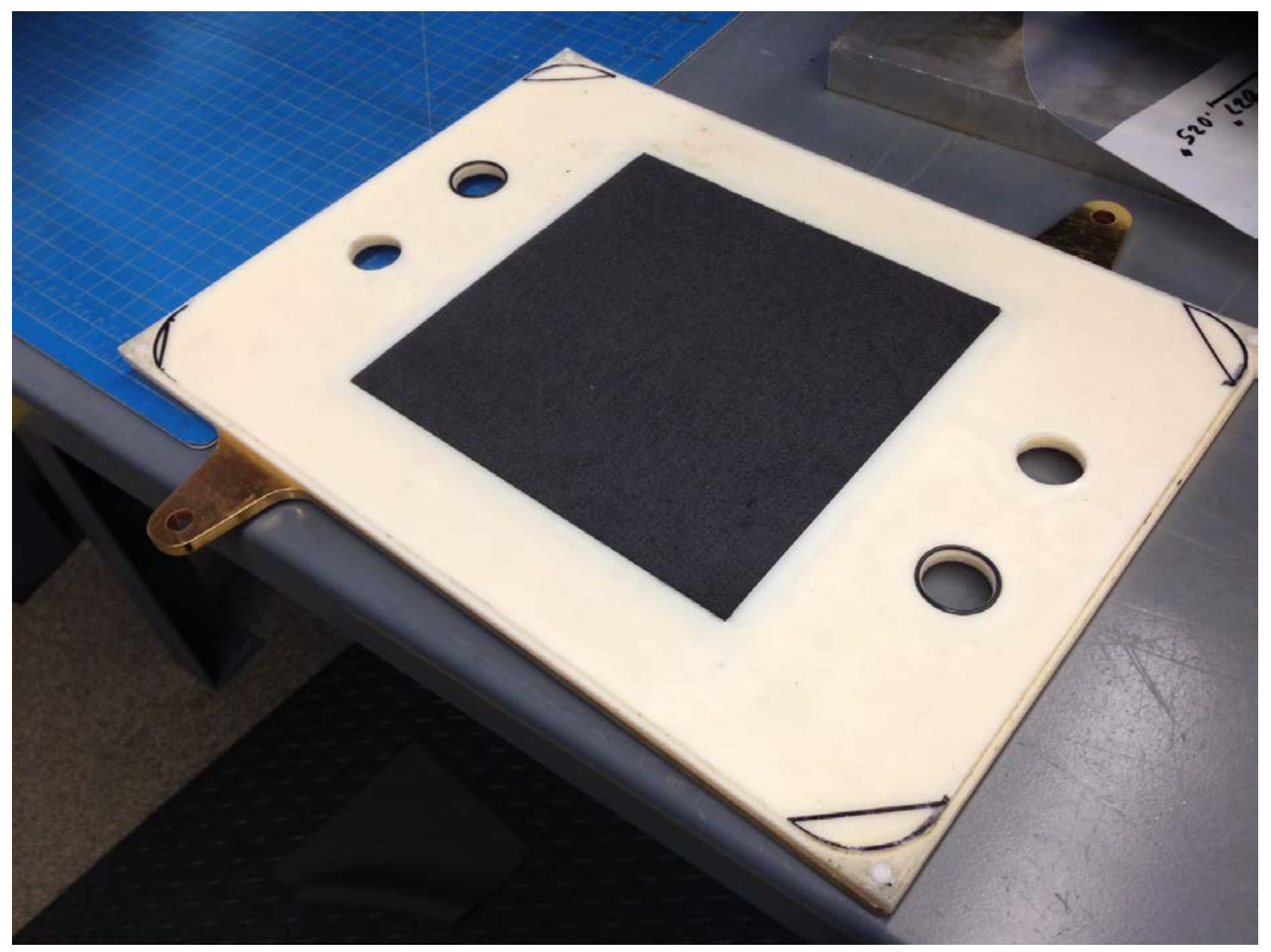

Fig. 4. kW-scale DFMA stack fabricated of only die-cut sheet goods.

Figure 5 illustrates the charge / discharge performance of the DFMA cell at the target operating $200 \mathrm{~mA} / \mathrm{cm}^{2}$ current density at $0.8 \mathrm{~L} / \mathrm{min}$ flow of posolyte and negolyte, $\mathrm{T}=35{ }^{\circ} \mathrm{C}, 50 \%$ state-ofcharge (SOC). A key parameter in characterizing the cell efficiency is the internal cell resistance that is measured during charge \& discharge. The DFMA cell, under the stated conditions, achieves a cell resistance that slightly exceeds the capabilities of the current traditional cell design that is fabricated using machining and molding processes. This result was rather unexpected, and suggests that the DFMA design may not involve any performance trade-offs to achieve disruptively lower costs. 


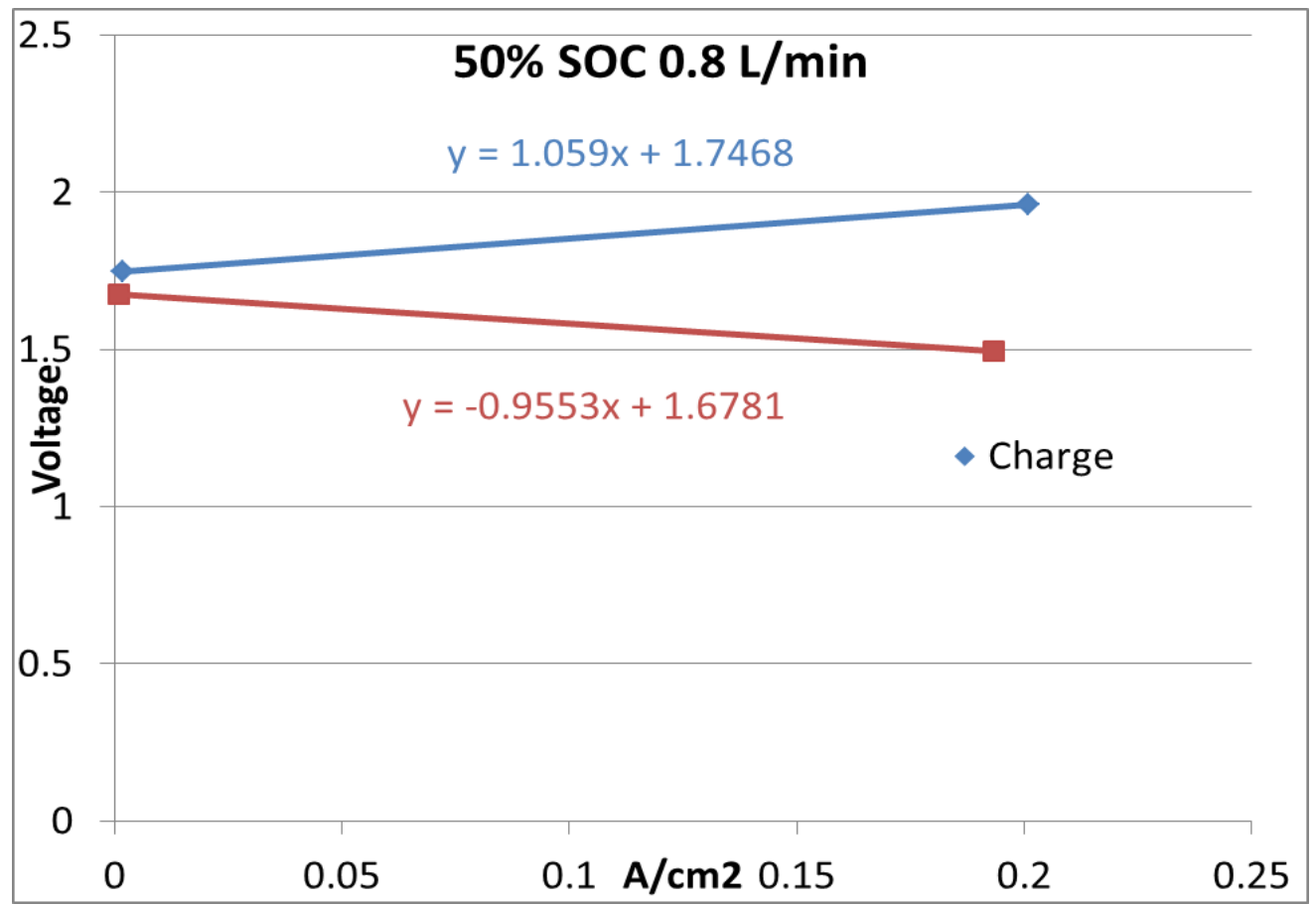

Fig. 5. Charge / discharge polarization performance of the DFMA cell using proprietary CCFB electrolytes. Conditions: $0.8 \mathrm{~L} / \mathrm{min}$ flow of posolyte \& negolyte, $\mathrm{T}=35^{\circ} \mathrm{C}, 50 \%$ state-of-charge (SOC).

\section{$1.3 \quad$ IMPACTS}

This MDF technical assessment project was highly successful. The team was able to demonstrate a viable manufacturing approach, develop roll to roll strategies for implementation, and scale the technology of devices to 5kW power. Technical advances on SunCatalytix' technology resulted in a successful acquisition of the company by Lockheed Martin. Lockheed Martin has completed the acquisition of substantially all of the assets of Sun Catalytix Corporation of Cambridge, Massachusetts, complementing existing Lockheed Martin capabilities in the area of energy management and efficiency. The purchase includes certain intellectual property, contracts, facilities and the transfer of the company's approximately 25 employees to Lockheed Martin.

\subsection{CONCLUSIONS}

- For improving efficiency and precision, a new mold with $1 \mathrm{~mm}$ thickness was designed and built.

- The new design gives the flexibility to select the bonding contact area out of three sizes.

- A version of the bonding conditions that were determined by ORNL were employed in the fabrication of the $400 \mathrm{~cm} 2 \mathrm{~kW}$-scale single, whose testing results indicate efficiency that meets or exceeds current cell designs

- Next steps for the DFMA technology is the scaling of the single $400 \mathrm{~cm} 2$ cell to multi-cell stacks to achieve higher power and increased manufacturing scale

SunCatalytix has been acquired by Lockheed Martin and is now the Lockheed Martin Energy Systems Division. Full market implementation is planned for the future. 


\section{PARTNER BACKGROUND}

Going forward, the operation will be known as Lockheed Martin Advanced Energy Storage, LLC and will be a wholly-owned subsidiary of Lockheed Martin reporting through the Corporation's Missiles and Fire Control business area.

The organization is an innovation-based company with advanced engineering and chemistry expertise in energy-related technologies and applications. The company has been developing an affordable, durable, safe and scalable energy storage technology. Current efforts focus on the design, synthesis and electrochemical testing of a novel energy storage chemistry derived from low cost, earthabundant materials.

Headquartered in Bethesda, Maryland, Lockheed Martin is a global security and aerospace company that employs approximately 113,000 people worldwide and is principally engaged in the research, design, development, manufacture, integration and sustainment of advanced technology systems, products and services. The Corporation’s net sales for 2013 were $\$ 45.4$ billion. 